\title{
Penentuan Beban dan Tinggi Rak yang Optimal terhadap Kebutuhan Energi Pekerja pada Area Penyimpanan di Mini Market X
}

\author{
Teguh Oktiarso ${ }^{*}$, Safitri ${ }^{2}$ \\ ${ }^{1,2}$ Program Studi Teknik Industri,Universitas Ma Chung, Malang, Indonesia \\ (*oktiarso@gmail.com)
}

\begin{abstract}
Abstrak - Aktivitas Manual Material Handling (MMH) merupakan aktivitas yang memerlukan energi lebih besar dibandingkan aktivitas lainnya di gudang penyimpanan. Penelitian ini dilakukan untuk menganalisis pengaruh tinggi rak, dan bobot barang terhadap kebutuhan energi para pekerja pada aktivitas MMH. Penelitian dilakukan dengan menggunakan desain eksperimen untuk mengetahui respon dua faktor terhadap kebutuhan energi pekerja melalui denyut jantung. Faktor bobot barang memiliki dua jenis, yaitu 5 kg dan $10 \mathrm{~kg}$ sedangkan faktor tinggi rak adalah $76 \mathrm{~cm}$ dan $126 \mathrm{~cm}$. Responden dari penelitian ini adalah empat pekerja laki-laki dalam rentang usia 18-25 tahun, sehingga rancangan dasar yang digunakan adalah Rancangan Acak Lengkap (RAL). Hasil uji ANOVA menunjukkan bahwa kedua faktor memiliki pengaruh terhadap kebutuhan energi antara faktor bobot barang terhadap kebutuhan energi. Hasil perhitungan konsumsi energi menunjukkan bahwa energi yang dibutuhkan pekerja untuk melakukan aktivitas MMH pada penelitian ini masih termasuk dalam kriteria beban kerja ringan.
\end{abstract}

Kata kunci: ANOVA; kebutuhan energi; MMH

\section{PENDAHULUAN}

Menurut American Material Handling Society, manual material handling (MMH) adalah seni dan ilmu yang meliputi penanganan (handling), pemindahan (moving), pengepakan (packaging), penyimpanan (storing), dan pengawasan (controlling) dari material dengan segala bentuknya (Muslimah dkk, 2005).

Aktivitas-aktivitas ini merupakan jenis kerja fisik yang membutuhkan energi fisik otot manusia sebagai sumber tenaganya. Aktivitas MMH memerlukan otot sebagai sumber tenaga sehingga konsumsi energi merupakan tolok ukur penentu berat ringannya suatu pekerjaan yang dapat dilihat dari peningkatan denyut jantung (Nurmianto, 2008).

Mini market X merupakan usaha mini market yang berada di Kota Malang di mana kebutuhan untuk pengisian barang dari truk ke gudang maupun dari gudang ke area penjualan masih dilakukan oleh manusia. Kebutuhan energi yang optimal para pekerjanya merupakan salah satu faktor untuk memepertahankan produktivitas bagian gudang agar selalu dapat menyuplai barang dengan cepat baik dari truk maupun ke area penjualan. Produktivitas yang menurun menyebabkan keterlambatan proses bongkar atau proses pengisian rak area penjualan yang berakibat turunnya pendapatan dari Mini market tersebut.

Tujuan dari penelitian ini adalah mengetahui pengaruh faktor tinggi rak, dan bobot barang terhadap kebutuhan energi pekerja yang melakukan aktivitas MMH dan menentukan konsumsi energi optimal yang dibutuhkan pekerja dalam melakukan aktivitas MMH.

\section{STUDI LITERATUR}

Ergonomi berasal dari bahasa Yunani "ergon" yang berarti kerja dan "nomos" yang berarti aturan. Ergonomi didefinisikan sebagai suatu proses sistematis dari perancangan untuk penggunaan manusia melalui penerapan dari pengetahuan tentang manusia terhadap peralatan yang digunakan, lingkungan, tugas yang dilakukan, dan sistem manajemen yang memandu keselamatan dan efisiensi operasi (Attwood, 2004). Penerapan ergonomi mencakup setiap komponen masyarakat untuk dapat menciptakan kenyamanan, kesehatan, keselamatan, dan produktivitas kerja yang maksimal. Tujuan utama dari penerapan ergonomi adalah pencapaian kualitas hidup manusia yang optimal di lingkungan sosial, keluarga, maupun tempat kerja.

Ergonomi dapat diterapkan di mana saja, kapan saja, dan pada aspek apa saja untuk dapat mencapai tiga tujuan. Pertama, penerapan ergonomi bertujuan untuk meningkatkan kesejahteraan fisik dan mental dengan melakukan pencegahan cedera dan penyakit akibat kerja, mengusahakan promosi dan kepuasan kerja, serta menurunkan beban kerja fisik dan mental. Kedua, meningkatkan kesejahteraan sosial dengan meningkatkan 
kualitas kontak sosial, mengelola dan mengoordinasi dengan tepat, serta meningkatkan jaminan sosial. Terakhir, penerapan ergonomi bertujuan untuk menciptakan keseimbangan rasional antara aspek teknis, ekonomis, antropologis, dan budaya dari setiap sistem kerja yang dilakukan, sehingga dapat tercipta kualitas kerja dan kualitas hidup tinggi (Tarwaka dkk., 2004).

Beban kerja adalah beban yang dialami oleh tenaga kerja karena pekerjaan yang dilakukannya (K3LH, 2016). Beban kerja akan mempengaruhi produktivitas dan efisiensi dari pekerja. Berdasarkan ilmu ergonomi, beban kerja seseorang harus sesuai dengan kemampuan fisik, kognitif, dan keterbatasan manusia yang menerimanya. Beban kerja dipengaruhi oleh faktor eksternal dan internal.

Menurut Astrand dan Rodahl (1977, dalam Tarwaka dkk., 2004), penilaian beban kerja fisik dapat dilakukan dengan dua metode, yaitu metode penilaian langsung dan metode tidak langsung. Metode langsung dilakukan dengan cara mengukur energi yang dikeluarkan (energy expenditure) melalui asupan oksigen selama bekerja. Sedangkan, metode tidak langsung dilakukan dengan cara menghitung denyut nadi selama bekerja. Menurut Konz (1996, dalam Tarwaka dkk., 2004), denyut jantung merupakan alat estimasi laju metabolisme yang baik, kecuali dalam kondisi emosi dan vasodilatasi.

Perancangan percobaan dilakukan untuk mengetahui respon dari suatu objek pada berbagai keadaan tertentu dengan memberikan perlakuan atau pengaturan keadaan lingkungan. Tiga hal penting dalam suatu percobaan adalah respon yang diberikan objek, keadaan tertentu yang diciptakan dengan sengaja untuk menimbulkan respon, dan keadaan lingkungan serta keragaman alami objek yang dapat mengganggu penelitian mengenai respon yang terjadi.(Gazpers, 1994) Menurut Kempthorne (dalam Gazpers, 1994), perancangan percobaan memiliki 9 langkah, yaitu pernyataan masalah, perumusan hipotesis, penentuan teknik dan rancangan percobaan, mempertimbangkan semua hasil dari prosedur statistika, melakukan percobaan, penerapan teknik statistika, penarikan kesimpulan, dan penilaian penelitian.

Percobaan faktorial merupakan percobaan yang memiliki dua faktor atau lebih. Rancangan dasar pada percobaan faktorial adalah rancangan acak lengkap (RAL), rancangan acak kelompok (RAK), dan rancangan bujur sangkar latin (RBSL). RAL merupakan rancangan yang paling sederhana dan berguna dalam percobaan laboratorium atau percobaan yang sifatnya relatif homogen. RAL memiliki beberapa keuntungan seperti denah percobaan yang lebih mudah, analisis statistika yang sederhana, penggunaan jumlah perlakuan dan ulangan yang fleksibel, dan kehilangan informasi relatif sedikit. RAL tepat diterapkan pada percobaan yang homogen atau relatif homogen dan untuk jumlah perlakuan yang terbatas (Gazpers, 1994).

Energy expenditure adalah jumlah energi atau kalori yang dibutuhkan oleh seseorang untuk melakukan kegiatan seperti bernafas, sirkulasi darah, mencerna makanan, atau kegiatan fisik (Mehta dkk, 2017). Perhitungan konsumsi energi berdasarkan denyut jantung dapat dilakukan menggunakan persamaan Astuti (Marasabessy, 2012) dengan rumus sebagai berikut:

$$
\mathrm{Y}=1,80411-0,0229038 \mathrm{X}+4,71733 \times \llbracket 10 \rrbracket \wedge(-4) \mathrm{X}^{\wedge} 2
$$

Di mana:

$\mathrm{Y}=$ Pengeluaran energi (kkal/menit)

$\mathrm{X}=$ Kecepatan denyut jantung per menit

Setelah kecepatan denyut jantung dikonversikan ke dalam energi, berikutnya dihitung konsumsi energi berdasarkan rumus berikut:

$$
\mathrm{KE}=\mathrm{Et}-\mathrm{Ei}
$$

Di mana:

$\mathrm{KE}=$ Konsumsi energi (kkal/menit)

Et $=$ Pengeluaran energi saat melakukan kerja (kkal/menit)

$\mathrm{Ei}=$ Pengeluaran energi saat istirahat $(\mathrm{kkal} / \mathrm{menit})$ 


\section{METODOLOGI}

Penelitian oleh Santoso (2006) bertujuan untuk menentukan MAWL untuk orang Indonesia berdasarkan variabel antropometri dan variabel lain yaitu frekuensi angkatan, tinggi angkatan, dan jarak vertikal dari angkatan. Tinggi angkatan yang digunakan pada penelitian tersebut adalah lutut, bahu, dan jangkauan tangan pada frekuensi 2, 4, dan 8 angkatan per menit. Ketinggian angkatan juga dapat dikategorikan menjadi tiga menurut Snook (1978, dalam Potvin dan Bent, 1997), yaitu floor to knuckle, knuckle to shoulders, dan shoulders to overhead reach.

Perancangan desain eksperimen kemudian dilakukan untuk mengetahui pengaruh dari tinggi rak, dan bobot barang terhadap kebutuhan energi. Penentuan sampel ditentukan untuk memperoleh data yang mencukupi dan mencapai tingkat akurasi yang diinginkan. Sampel yang akan diambil adalah pria berusia 18-25 tahun. Pengambilan sampel dilakukan dengan menggunakan teknik Dispropotionate Stratified Random Sampling. Penentuan jumlah sampel akan menggunakan uji Federer untuk mengetahui jumlah perulangan yang akan diambil.

Setelah mendapatkan jumlah sampel, eksperimen dilakukan pada pria berusia 18-25 tahun. Terdapat dua faktor pada penelitian ini, yaitu tinggi rak, dan bobot barang. Eksperimen dilakukan dengan mengukur denyut jantung responden menggunakan alat pengukur denyut jantung. Uji normalitas dan homogenitas kemudian dilakukan untuk mengetahui normal atau tidaknya distribusi data. Pengolahan data parametrik dilakukan jika data terdistribusi normal dan homogen. Pengolahan data dilakukan menggunakan uji ANOVA, dan selanjutnya dilakukan uji hipotesis. Melalui pengolahan data ini akan diketahui ada atau tidaknya interaksi untuk kemudian dilakukan analisis hasil. Jika terdapat minimal satu hipotesis yang menyatakan adanya pengaruh interaksi dalam percobaan tersebut, uji lanjut menggunakan uji Duncan akan dilakukan untuk mengetahui pengaruhpengaruh sederhana dalam pengaruh interaksi tersebut.

Hasil dari pengolahan data akan dianalisis untuk dapat mengetahui pengaruh dari ketiga faktor terhadap kebutuhan energi dengan denyut jantung sebagai parameter. Kemudian, perhitungan kebutuhan energi dilakukan berdasarkan data denyut jantung sebelum dan sesudah dilakukannya eksperimen. Berdasarkan penelitian yang telah dilakukan, dapat ditarik kesimpulan yang berkaitan dengan hubungan tinggi rak, dan bobot barang terhadap kebutuhan energi.

\section{HASIL DAN DISKUSI}

\section{A. Hasil Observasi}

Respons yang diharapkan dari responden pada penelitian ini adalah respons yang dapat merepresentasikan kebutuhan energi responden terhadap suatu perlakuan. Respons yang digunakan dalam penelitian ini adalah angka detak jantung yang didapatkan dari aktivitas mengangkat dan menurunkan barang selama maksimal 5 menit dengan frekuensi angkatan 4 kali per menit. Responden akan diukur detak jantungnya per menit menggunakan Mi Band 4 pada saat melakukan aktivitas mengangkat dan menurunkan barang ke atas rak dengan ketinggian yang berbeda. Hasil observasi dapat dijabarkan pada tabel berikut:

Tabel 1

Jenis Pekerjaan MMH di gudang Mini Market X

\begin{tabular}{|c|c|c|c|}
\hline No. & Contoh Barang & Berat & Jenis Aktivitas \\
\hline 1. & Sak gula & $50 \mathrm{~kg}$ & $\begin{array}{l}\text { Dipindahkan ke troli } \\
\text { Dibawa dengan troli }\end{array}$ \\
\hline 2. & $\begin{array}{l}\text { Karton tepung, karton } \\
\text { saus, karton selai }\end{array}$ & $10 \mathrm{~kg}-12 \mathrm{~kg}$ & $\begin{array}{l}\text { Dipanggul dari lantai } 1 \text { ke lantai } 2 \text { (10 meter) } \\
\text { Diangkat ke rak setinggi } 76 \mathrm{~cm} \text { dan } 126 \mathrm{~cm} \\
\text { Diangkat dan ditumpuk sampai }+1 \text { meter }\end{array}$ \\
\hline 3. & Beras & $5 \mathrm{~kg} \& 25 \mathrm{~kg}$ & Diangkat dan ditumpuk sampai $+1,5$ meter \\
\hline 4. & $\begin{array}{l}\text { Karton santan, karton } \\
\text { silica gel }\end{array}$ & $1 \mathrm{~kg}$ & $\begin{array}{c}\text { Diangkat ke rak setinggi } 76 \mathrm{~cm} \text { dan } 126 \mathrm{~cm} \\
\text { Dipindah (tidak bungkuk) }\end{array}$ \\
\hline
\end{tabular}


Perlakuan untuk pengambilan data selama eksperimen dapat dijabarkan pada keterangan yang ada pada di bawah ini:

1. A = kombinasi perlakuan bobot barang $5 \mathrm{~kg}$, dan tinggi rak $76 \mathrm{~cm}$.

2. $\mathrm{B}=$ kombinasi perlakuan bobot barang $10 \mathrm{~kg}$, dan tinggi rak $76 \mathrm{~cm}$.

3. $\mathrm{C}=$ kombinasi perlakuan bobot barang $5 \mathrm{~kg}$, dan tinggi rak $126 \mathrm{~cm}$.

4. $\mathrm{D}=$ kombinasi perlakuan bobot barang $10 \mathrm{~kg}$, dan tinggi rak $126 \mathrm{~cm}$.

Keempat perlakuan tersebut diuji pada empat responden untuk mengetahui bagaimana pengaruh berat barang dan tinggi rak terhadap kebutuhan energi keempat responden. Gambar proses pelaksanaan perlakuan dapat dijabarkan sebagai berikut:

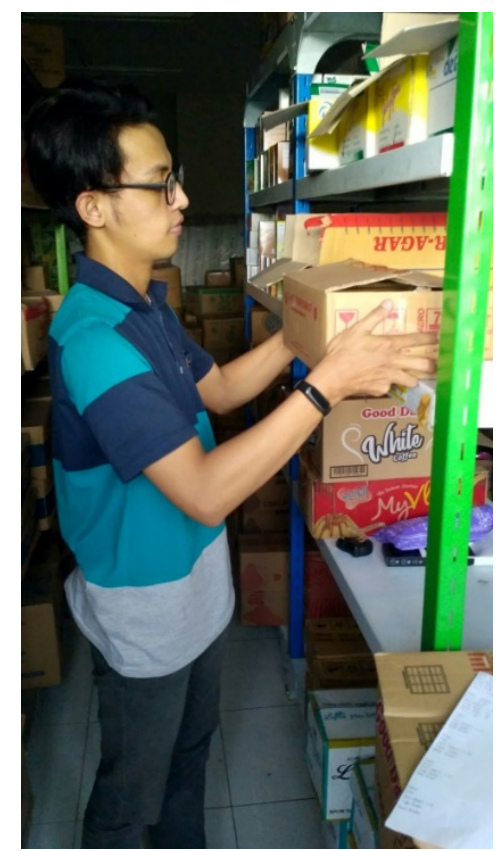

Gambar 1. Metode pelaksanaan oleh responden

\section{B. Pelaksanaan Ekperimen}

Banyaknya sampel ditentukan menggunakan rumus Federer dengan hasil 4 kali perulangan untuk setiap perlakuan. Sehingga, besar sampel yang akan diambil pada 8 kombinasi perlakuan adalah 32 sampel. Terdapat 4 orang responden, sehingga setiap responden akan memperoleh 8 perlakuan untuk mencapai 32 sampel.

Aktivitas yang akan disimulasikan adalah aktivitas mengangkat dan menurunkan barang dengan bobot barang $5 \mathrm{~kg}$ dan $10 \mathrm{~kg}$. Barang yang digunakan adalah karton selai Lepatta Tropicana CF yang memiliki isi 2 pak dan berat masing-masing $5 \mathrm{~kg}$. Karton selai isi 1 pak $(5 \mathrm{~kg})$ akan digunakan untuk sebagai taraf $5 \mathrm{~kg}$, sedangkan karton selai isi 2 pak $(10 \mathrm{~kg})$ akan digunakan sebagai taraf $10 \mathrm{~kg}$.

Frekuensi pengangkatan adalah $4 \mathrm{kali} /$ menit, didasarkan pada hasil observasi pada salah satu jenis barang yaitu 2000 karton Teh Pucuk yang membutuhkan waktu 4 jam untuk diangkat ke gudang. Proses pengangkatan melibatkan 2 hingga 3 orang sehingga setiap orang dapat mengangkat sekitar 4 karton/menit. Posisi stoop lift akan diterapkan pada percobaan ini karena para pekerja terbiasa mengangkat pada posisi stoop lift. Menurut Lopez dan Tucker (2017), teknik angkat squat lift lebih direkomendasikan daripada stoop lift. 


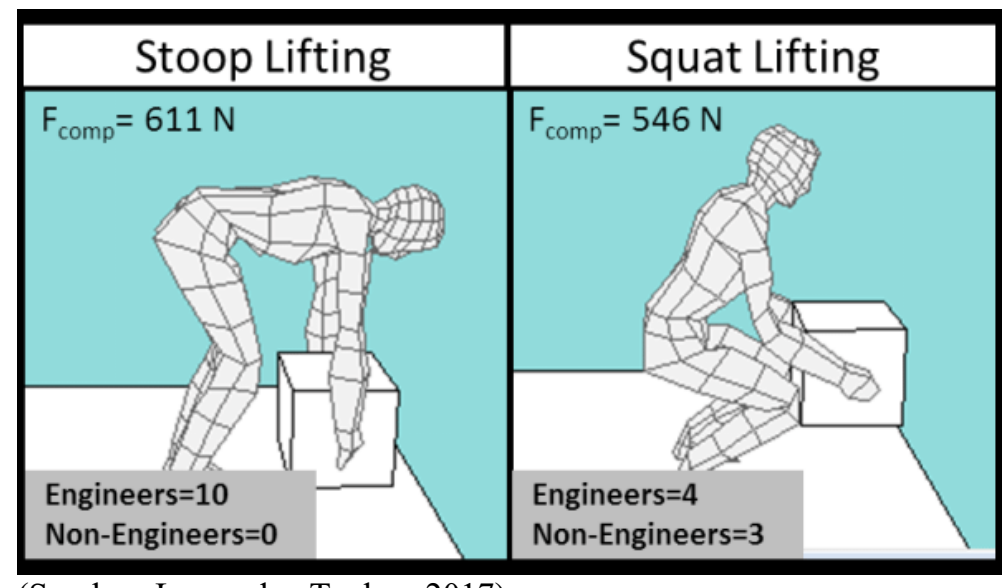

(Sumber: Lopez dan Tucker, 2017)

Gambar 2. Posisi Angkat Stoop Lift dan Squat Lift

\section{Pengujian Hipotesis}

Berdasarkan hasil pengujian kedua faktor tersebut terhadap kebutuhan energi yang atanya berupa denyut jantung (bpm) dengan menggunakan software Minitab 16, hasil dari uji tersebut adalah sebagai berikut:

Tabel 2

Jenis Pekerjaan MMH di gudang Mini Market X

\begin{tabular}{lllll}
\hline Sumber Keragaman & $\boldsymbol{F}$ hitung & $\boldsymbol{F}$ tabel & $\boldsymbol{P}$-value & Keterangan \\
\hline A (Bobot Barang) & 193,52 & 4,26 & 0,000 & Tolak $\mathrm{H}_{0}$ \\
B (Tinggi Rak) & 39,65 & 4,26 & 0,000 & Tolak $\mathrm{H}_{0}$ \\
AB & 0,02 & 4,26 & 0,881 & Terima $\mathrm{H}_{0}$
\end{tabular}

Pada rancangan percobaan ini, hipotesis yang dikembangkan adalah sebagai berikut:

a. $\mathrm{H} 0: \beta j=0$, berarti faktor bobot barang tidak memengaruhi respons terhadap kebutuhan energi.

$\mathrm{H} 1$ : minimal ada satu $\beta j \neq 0$, berarti faktor bobot barang memengaruhi respons terhadap kebutuhan energi.

b. H0: $\gamma_{-} \mathrm{k}=0$, berarti faktor tinggi rak tidak memengaruhi respons terhadap kebutuhan energi.

H1: minimal ada satu $\gamma_{-} \mathrm{k} \neq 0$, berarti faktor tinggi rak memengaruhi respons terhadap kebutuhan energi.

c. H0: $(\beta \gamma) j k=0$, berarti tidak ada pengaruh interaksi antara bobot barang dan tinggi rak terhadap kebutuhan energi.

$\mathrm{H1}$ : minimal ada satu $(\beta \gamma) j k \neq 0$, berarti ada pengaruh interaksi antara bobot barang dan tinggi rak terhadap kebutuhan energi.

Hasil uji ANOVA untuk mencari interaksi kedua faktor tersebut terhadap kebutuhan energi mendapatkan hasil yang ada pada tabel 2 didapatkan bahwa bobot barang mempengaruhi kebutuhan energi pekerjanya karena hasil p-valuenya adalah 0 atau kurang dari 5\%. Hubungan ini disebabkan karena semakin berat barang yang diangkat, kebutuhan energinya akan meningkat. Demikian pula dengan tinggi rak juga berkorelasi dengan kebutuhan energi karyawan mini market. Semakin tinggi dan berat barang yang harus diangkat, semakin tinggi pula kebutuhan energi yang dikeluarkan. Plot response untuk kedua faktor tersebut dapat dilihat sebagai berikut: 


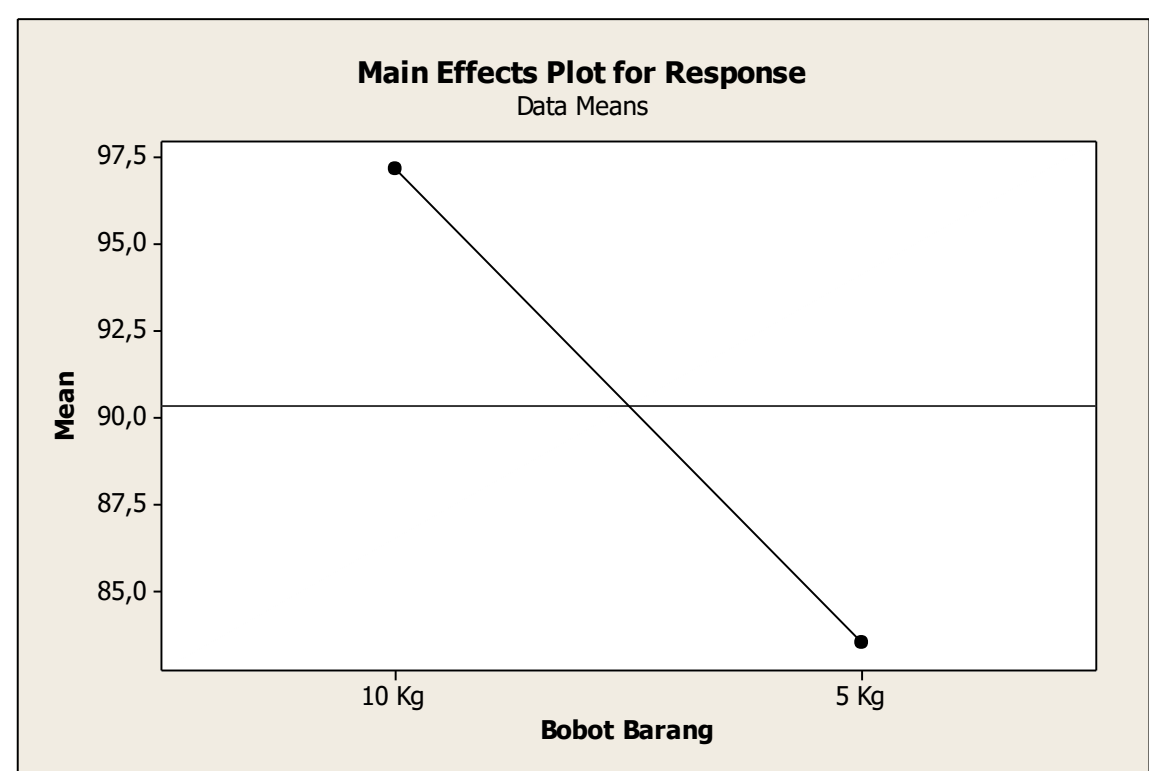

Gambar 3. Grafik Pengaruh Utama Faktor Bobot Barang Terhadap Kebutuhan Energi

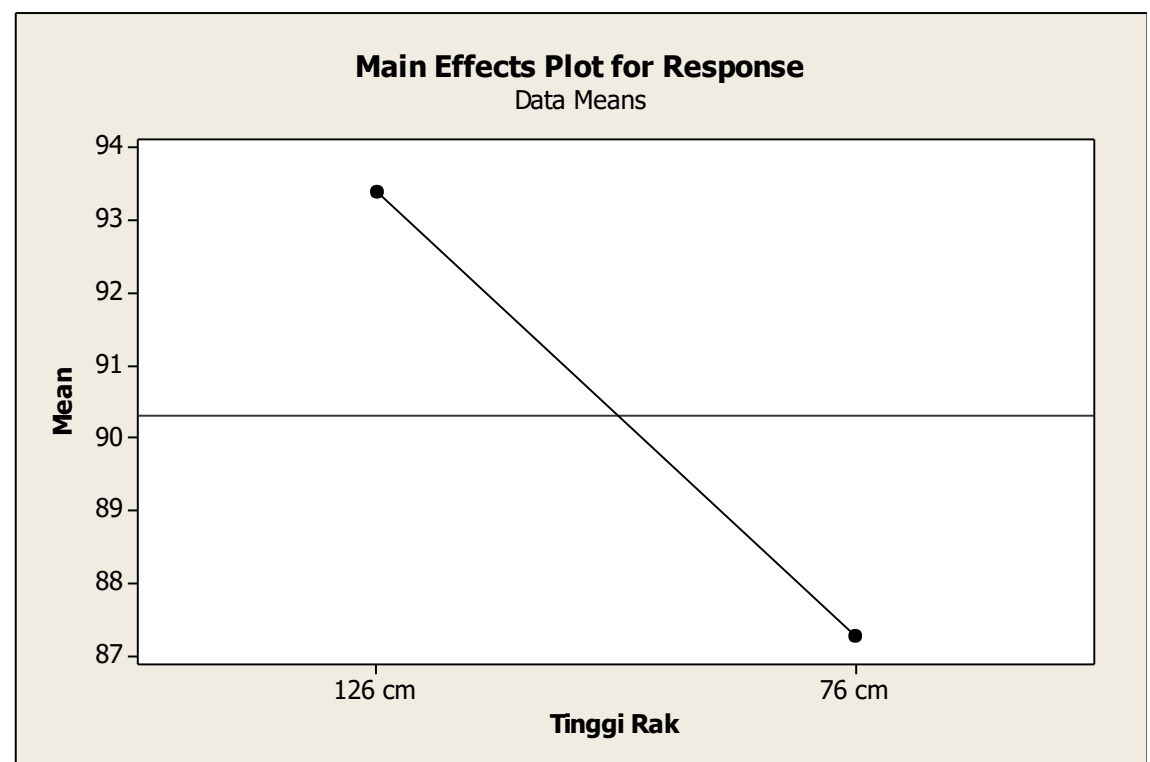

Gambar 4. Grafik Pengaruh Utama Faktor Tinggi Rak Terhadap Kebutuhan Energi

Hasil yang terbalik didapatkan dari interaksi A dan B yaitu tinggi dan bobot barang yang ternyata tidak mempengaruhi kebutuhan energi karyawan. Hasil ini disebabkan karena kombinasi kedua faktor ini membuat kebutuhan karyawan menjadi lebih stabil sehingga perbedaan kebutuhan energinya tidak banyak terpengaruh. Interaksi antara kedua faktor tersebut dapat digambarkan sebagai berikut: 


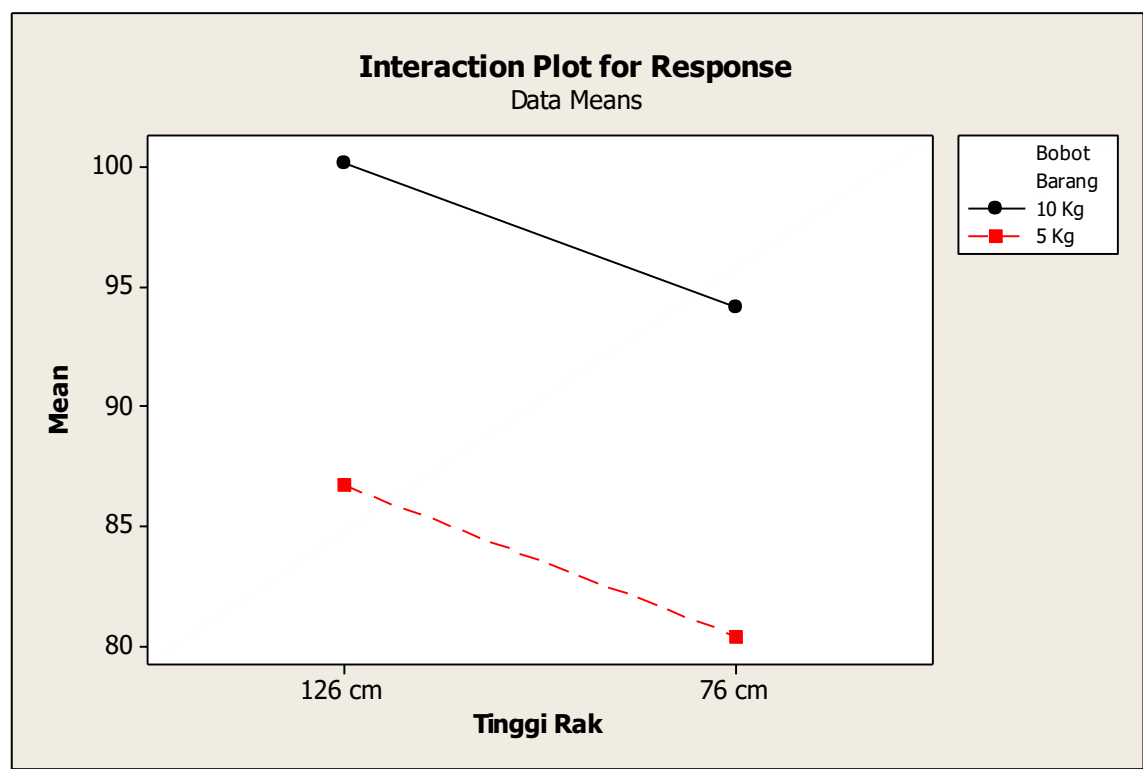

Gambar 5. Interaksi Antara Faktor Bobot Barang dan Tinggi Rak Terhadap Respons Kebutuhan Energi

Berdasarkan hasil di atas, terlihat tidak ada pengaruh interaksi antara faktor bobot barang (A) dan tinggi rak (B). Respons tertinggi dari faktor bobot barang $10 \mathrm{~kg}$ (A2) ada pada tinggi rak $126 \mathrm{~cm}$ (B2) dan respons terendah ada pada tinggi rak $76 \mathrm{~cm}(\mathrm{~B} 1)$. Begitu juga dengan faktor bobot barang $5 \mathrm{~kg}$ (A1), respons tertinggi terdapat pada tinggi rak $126 \mathrm{~cm}$ (B2) dan respons terendah ada pada tinggi rak $76 \mathrm{~cm}(\mathrm{~B} 1)$.

\section{KESIMPULAN}

Hasil uji ANOVA menunjukkan bahwa kedua faktor memiliki pengaruh terhadap kebutuhan energi. Hasil uji ANOVA juga menunjukkan adanya pengaruh interaksi antara faktor bobot barang terhadap kebutuhan energi. Sementara itu, hasil uji ANOVA menunjukan bahwa tidak ada pengaruh interaksi antara faktor bobot barang dan faktor tinggi rak terhadap kebutuhan energi. Uji lanjutan kemudian dilakukan untuk menguji pengaruh-pengaruh sederhana dari pengaruh interaksi faktor A dan B.

Perhitungan kebutuhan energi berdasarkan denyut jantung kemudian dilakukan menggunakan persamaan Astuti. Nilai rata-rata konsumsi energi responden saat bekerja adalah $<2,5 \mathrm{kkal} / \mathrm{menit}$ dan nilai rata-rata denyut jantung kurang dari $100 \mathrm{bpm}$. Dengan demikian, dapat disimpulkan bahwa energi yang dibutuhkan pekerja untuk melakukan aktivitas MMH pada penelitian ini masih termasuk dalam kriteria beban kerja ringan.

\section{PENGHARGAAN}

Penelitian ini dapat terlaksana dengan bantuan Hibah Penelitian Terapan Unggulan Perguruan Tinggi (PTUPT) dari Direktorat Jenderal Pendidikan Tinggi Kementerian Pendidikan dan Kebudayaan Indonesia.

\section{DAFTAR PUSTAKA}

Attwood, D.A., Joseph, M.D., dan Mary, E.D. (2004). Ergonomic Solutions for Process Industries, Elsevier. USA.

Gaspersz, V. (1994). Metode Perancangan Percobaan, CV. Armico, Bandung, Indonesia.

K3LH. (2016). Beban Kerja Fisik Berdasarkan Jumlah Kebutuhan Kalori. Tulisan K3LH, Jakarta, Indonesia. Lopez, C.E., Tucker, C.S., 2017, Towards Real-time Ergonomics Feedback and Educational Content With The Use of Co-Robots, Mid-Atlantic ASEE Conference, Pennsylvania, 6-7 October

Marasabessy, R.S. (2012). Penentuan Maximum Acceptable Weight Limit (MAWL) dengan Menggunakan

Pendekatan Fisiologi, ARIKA, 6(1):39-46. 
Mehta, J.N., Gupta, A.V., Raval, N., dan Hasnani, N. (2017). Physiological Cost Index of Different Body Mass Index and Age of an Individual, National Journal of Physiology, Pharmacy, and Pharmacology, 7:13131317.

Muslimah, E., Pratiwi, I., dan Rafsanjani, F. (2006). Analisis Manual Material Handling Menggunakan NIOSH Equation, Jurnal Ilmiah Teknik Industri, 5(2):53-60.

Nurmianto, E. (2008). Ergonomi: Konsep Dasar dan Aplikasinya, Edisi kedua, Guna Widya, Surabaya, Indonesia.

Potvin, J.R., Bent, L.R., 1997, NIOSH Equation Horizontal Distances Associated with The Liberty Mutual (Snook) Lifting Table Box Widths, Ergonomics, 40(6):650-655.

Tarwaka, Bakri, S.HA, dan Sudiajeng, L. 2004, Ergonomi untuk Keselamatan, Kesehatan Kerja, dan Produktivitas, cetakan pertama, Uniba Press, Surakarta, Indonesia. 